\title{
PENDIDIKAN KARAKTER \\ SEBAGAI BAGIAN DARI REVOLUSI MENTAL
}

Oleh: Petrus Honggo

\begin{abstract}
Abstrak:
rtikel ini bertujuan untuk memperkenalkan nilai-nilai yang perlu dikembangkan dalam Pendidikan Karakter. Melalui pengembangan nilai-nilai ini, pendidikan dalam level manapun telah mengambil bagian dalam gerakan Revolusi Mental. Revolusi Mental adalah istilah yang diperkenankan oleh Presiden Joko Widodo sejak masa kampanye Capres pada tahun 2014. Revolusi Mental diharapkan bisa mewarnai segala sendi kehidupan bangsa yang telah carut-marut akibat peminggiran terhadap nilai-nilai. Perwujudan Revolusi Mental salah satunya dijalankan melalui upaya memperkenalkan nilai-nilai melalui Pendidikan Karakter. Pendidikan karakter penting artinya sebagai penyeimbang kecakapan kognitif. Perhatian yang kurang terhadap pendidikan karakter menyebabkan kepincangan dalam kehidupan peserta didik yang kemudian akan terbawa ke dalam kehidupan sosial.
\end{abstract}

Kata Kunci:Pendidikan Karakter, Revolusi Mental, Nilai-Nilai.

\section{Pendahuluan}

Dalam Pembukaan Undang-Undang Dasar 1945 alinea 4 tentang tujuan Negara"...mencerdaskan kehidupan bangsa", dan dasar Negara"...Ketuhanan Yang Maha Esa, kemanusiaan yang adil dan beradab, persatuan Indonesia, dan kerakyatan yang dipimpin oleh hikmat kebijaksanaan dalam permusyawaratan perwakilan, serta dengan mewujudkan keadilan social bagi seluruh rakyat Indonesia."Hal ini mengandung arti bahwa Negara Republik Indonesia memiliki misi, antara lain mewujudkan bangsa Indonesia yang cerdas sesuai dengan esensi dan makna dasar Negara tersebut. Dalam Tap MPR No.X/MPR/1998 tentang pokok-pokok Reformasi Pembangunan Dalam Rangka Penyelamatan dan Normalisasi Kehidupan Nasional Sebagai Haluan Negara, khusunya pada Bab IV huruf D mengenai Agama dan Sosial Budaya, butirl.f. yakni agenda yang harus dijalankan adalah : "Peningkatan akhlak mulia dan budi luhur dilaksanakan melalui pendidikan budi pekerti di sekolah".

Dalam penerapan Penguatan Pendidikan Karakter dilatarbelakangi adanya amanat Undang-undang Pendidikan Nasional No. 20 Tahun 2003 pasal 3 yang menyatakan bahwa Pendidikan Nasional berfungsi mengembangkan kemampuan dan watak serta peradaban bangsa yang bermartabat dalam rangka mencerdaskan kehidupan bangsa, bertujuan untuk berkembangnya potensi peserta didikagar menjadi manusia yang beriman dan bertakwa kepada Tuhan Yang Maha Esa, berahlak mulia, sehat, berilmu, cakap, kreatif, mandiri dan menjadi warga negara yang demokratis dan bertanggungjawab.Program Penguatan Pendidikan Karakter ini juga sejalan dengan agenda "NAWACITA" Presiden Jokowi, nomor 8 berupa penguatan revolusi karakter bangsa melalui budi pekerti dan pembangunan karakter peserta didik sebagai bagian dari revolusi mental.Penguatan Pendidikan Karakter ini juga dalam rangka mewujudkan generasi yang berkepribadian dalam kebudayaan seperti pada trisakti.Menurut UU No. 20 tahun 2003, pendidikan adalah usaha sadar dan terencana untuk mewujudkan suasana belajar dan proses pembelajaran agar peserta didik secara aktif mengembangkan potensi dirinya untuk memiliki kekuatan spiritual keagamaaan, pengendalian diri, kepribadian, kecerdasan, akhlak mulia, serta ketrampilan yang diperlukan dirinya, masyarakat, bangsa, dan Negara. 
Pengertian pendidikan menurut H. Horne, adalah proses yang terus menerus (abadi) dari penyesuaian yang lebih tinggi bagi makhluk manusia yang telah berkembang secara fisik dan mental, yang bebas dan sadar kepada Tuhan, seperti termanifestasi dalam alam sekitar intelektual, emosional dan kemanusiaan dari manusia.Karena itu istilah karakter dihubungkan dan dipertukarkan dengan istilah etika, akhlak, dan atau nilai dan berkaitan dengan kekuatan moral, berkonotasi positif, bukan netral.Sedangkan Karakter menurut Kamus Besar Bahasa Indonesia (2008) merupakan sifat-sifat kejiwaan, akhlak atau budi pekerti yang membedakan seseorang dari yang lain. Dengan demikian karakter adalah nilai-nilai yang unik-baik yang terpateri dalam diri dan terejawantahkan dalam perilaku. (Ensikolodi Umum hal. 527) Karakterologi, cabang psikologi yang mempelajari tabiat atau watak (karakter). Karakter secara koheren memancar dari hasil olah pikir, olah hati, olah rasa dan karsa, serta olahraga seseorang atau sekelompok orang.Karakter juga sering diasosiasikan dengan istilah temperamen yang lebih memberi penekanan pada definisi psikososial yang dihubungkan dengan pendidikan dan konteks lingkungan.

Ditinjau dari sudut pandang behaviorial karakter lebih menekankan pada unsur somatopsikis yang dimiliki seseorang sejak lahir. Dengan demikian dapat dikatakan bahwa proses perkembangan karakter pada seseorang dipengaruhi oleh banyak faktor yang khas yang ada pada orang yang bersangkutan yang juga disebut faktor bawaan (nature) dan lingkungan (nurture) dimana orang yang bersangkutan tumbuh dan berkembang. Faktor bawaan boleh dikatakan berada di luar jangkauan masyarakat dan individu untuk mempengaruhinya, sedangkan faktor lingkungan merupakan faktor yang berada pada jangkauan masyarakat dan individu.Jadi usaha pengembangan pendidikan karakter seseorang dapat dilakukan oleh masyarakat atau individu sebagai bagian dari lingkungan melalui rekayasa faktor lingkungan.

\section{Faktor-Faktor yang Mempengaruhi Pendidikan Karakter}

Faktor lingkungan dalam konteks pendidikan karakter memiliki peran yang sangat peting karena perubahan perilaku peserta didik sebagai hasil dari proses pendidikan karakter sangat ditentukan oleh faktor lingkungan ini. Dengan kata lain pembentukan dan rekayasa lingkungan yang mencakup diantaranya lingkungan fisik dan budaya sekolah, manajemen sekolah, kurikulum, pendidik, dan metode mengajar. Pembentukan karakter melalui rekayasa faktor lingkungan dapat dilakukan melalui: keteladanan, intervensi, pembiasaan yang dilakukan secara konsisten, dan penguatan.

Dengan kata lain perkembangan dan pembentukan karakter memerlukan pengembangan keteladanan yang ditularkan, diintervensi melalui proses pembelajaran, pelatihan, pembiasaan terus-menerus dalam jangka panjang yang dilakukan secara konsisten dan penguatan serta harus dibarengi dengan nilai-nilai luhur. Nilainilai luhur ini harus dimulai dari para pendidik dan orang dewasa agar peserta didik dapat meniru dan meneladani sikap dan kepribadian yang ditampilkan.

\section{Pendidikan Menurut Undang-Undang dan Para Ahli}

Pendidikan memang tak lepas dari makna dan definisi.Dalam dunia pendidikan banyak sekali istilahistilah yang dipakai dan memerlukan pembahasan mengenai hal definisi atau pengertiannya.Berikut adalah beberapa pengertian Pendidikan menurut Undang-Undang dan para ahli yang dikutip dari beberapa sumber :

\section{Pendidikan Menurut UU Sisdiknas}

Pendidikan adalah usaha sadar dan terencana untuk mewujudkan suasana belajar dan proses pembelajaran agar peserta didik secara aktif mengembangkan potensi dirinya untuk memiliki kekuatan spiritual keagamaan, 
pengendalian diri, kepribadian, kecerdasan, akhlak mulia, serta keterampilan yang diperlukan dirinya, masyarakat, bangsa dan Negara.

\section{Pendidikan Menurut Carter V. Good}

Pendidikan adalah proses perkembangan kecakapan seseorang dalam bentuk sikap dan perilaku yang berlaku dalam masyarakatnya. Proses sosial dimana seseorang dipengaruhi oleh sesuatu lingkungan yang terpimpin (khususnya di sekolah) sehingga ia dapat mencapai kecakapan sosial dan mengembangkan kepribadiannya.

3. Pendidikan Menurut Godfrey Thomson

Pendidikan adalah pengaruh lingkungan atas individu untuk menghasilkan perubahan yang tepat didalam kebiasaan tingkah lakunya, pikirannya dan perasaannya.

\section{Pendidikan Menurut UNESCO}

UNESCO menyebutkan bahwa: "education is now engaged is preparinment for a tipe society which does not yet exist" atau bahwa pendidikan itu sekarang adalah untuk mempersiapkan manusia bagi suatu tipe masyarakat yang masih belum ada. Konsep system pendidikan mungkin saja berubah sesuai dengan perkembangan masyarakat dan pengalihan nilai-nilai kebudayaan (transfer of culture value).Konsep pendidikan saat ini tidak dapat dilepaskan dari pendidikan yang harus sesuai dengan tuntutan kebutuhan pendidikan masa lalu,sekarang,dan masa datang.

\section{Pendidikan Menurut Thedore Brameld}

"Education as power means copetent and strong enough to enable us, the majority of people,to decide what kind of a world". (Pendidikan sebagai kekuatan berarti mempunyai kewenangan dan cukup kuat bagi kita, bagi rakyat banyak untuk menentukan suatu dunia yang macam apa yang kita inginkan dan macam mana mencapai tujuan semacam itu).

\section{Pendidikan Menurut Rebert W. Richley}

Robert W. Richey menyebutkan bahwa; The term "Education" refers to the broad funcition of preserving and improving the life of the group through bringing new members into its shared concem. Education is thus a far broader process than that which occurs in schools. It is an essential social activity by which communities continue to exist. In Communities this function is specialzed and institutionalized in formal education, but there is always the education, out side the school with which the formal process is related. (Istilah pendidikan mengandung fungsi yang luas dari pemelihara dan perbaikan kehidupan suatu masyarakat, terutama membawa warga masyarakat yang baru mengenal tanggung jawab bersama di dalam masyarakat. Jadi pendidikan adalah suatu proses yang lebih luas daripada proses yang berlangsung di dalam sekolah saja. Pendidikan adalah suatu aktivitas sosial yang memungkinkan masyarakat tetap ada dan berkembang. Di dalam masyarakat yang kompleks, fungsi pendidikan ini mengalami spesialisasi dan melembaga dengan pendidikan formal yang senantiasa tetap berhubungan dengan proses pendidikan informal di luar sekolah).

Dari sini Penulismelihat pendidikan karakter di lembaga pendidikan yang ada di banyak tempat masih membutuhkan pembenahan secara teratur mulai dari keluarga.Karena itu keluarga merupakan lembaga pendidikan pertama dan utama yang ditanamkan nilai-nilai keagamaan dan nilaia moral yang diterima anak sehari-hari.Seperti apakah ini? Seperti salam, sapah dan ramah. Mengajarkan berdoa kepada anak itu dari orang tua, mengajarkan selamat pagi itu juga dari rumah dan lain-lain.

Konsili Vatikan II dalam "Gravissimum Educationis” bahwa tujuan pendidikan dalam arti sesungguhnya ialah: mencapai pembinaan pribadi manusia dalam perspektif tujuan terakhirnya dan demi kesejahteraan kelompok-kelompok masyarakat, ... manusia termasuk anggota, ..., berperan untuk menunaikan tugas dan kewajibanya (Dokumen KV. II, hal.293.cet.pertama 1993).Jadi manusia sebagai anggota Gereja yang tugasnya 
mewartakan Kerajaan Allah di tengah dunia yang sedang berporak poranda ini.Karena itu pendidikan karakter mesti dijiwai oleh Roh Kristus yang menjadi penggerak utama dalam dunia pendidikan.

\section{Pilar-Pilar Pendidikan Karakter}

Pendidikan karakter didasarkan pada enam nilai etis bahwa setiap orang dapat menyetujui nilai-nilai yang tidak mengandung politis, religius, atau bias budaya. Beberapa hal di bawah ini yang dapat dijelaskan untuk membantu siswa memahami Enam Pilar Pendidikan Berkarakter, yaitu sebagai berikut: Pertama, trustworthiness (kepercayaan). Hal ini nampak dalam sikap jujur, tidak menipu, menjiplak atau mencuri, jadilah handal - melakukan apa yang anda katakan anda akan melakukannya, minta keberanian untuk melakukan hal yang benar, bangun reputasi yang baik, patuh-berdiri dengan keluarga, teman dan negara.Kedua, recpect (respek).Nampak dalam bersikap toleran terhadap perbedaan, gunakan sopan santun, bukan bahasa yang buruk, pertimbangkan perasaan orang lain, jangan mengancam, memukul atau menyakiti orang lain, damailah dengan kemarahan, hinaan dan perselisihan.Ketiga, responsibility(tanggungjawab).Pilar ini ter-realisasi dalam mental selalu melakukan yang terbaik, gunakan kontrol diri, disiplin, berpikirlah sebelum bertindakmempertimbangkan konsekuensi, bertanggung jawab atas pilihan anda.Keempat, fairness(keadilan). Contohnya: bermain sesuai aturan, ambil seperlunya dan berbagi, berpikiran terbuka; mendengarkan orang lain, jangan mengambil keuntungan dari orang lain, jangan menyalahkan orang lain sembarangan.Kelima, caring(peduli).Bersikaplah penuh kasih sayang dan menunjukkan anda peduli, ungkapkan rasa syukur, maafkan orang lain, membantu orang yang membutuhkan.Keenam, citizenship(kewarganegaraan).Menjadikan sekolah dan masyarakat menjadi lebih baik, bekerja sama, melibatkan diri dalam urusan masyarakat,menjadi tetangga yang baik, mentaati hukum dan aturan, menghormati otoritas, melindungi lingkungan hidup.

\section{Tujuan, Fungsi dan Media Pendidikan karakter \& Nilai-nilai Pembentuk Karakter}

Pendidikan karakter pada intinya bertujuan membentuk bangsa yang tangguh, kompetitif, berakhlak mulia, bermoral, bertoleran, bergotong royong, berjiwa patriotik, berkembang dinamis, berorientasi ilmu pengetahuan dan teknologi yang semuanya dijiwai oleh iman dan takwa kepada Tuhan yang Maha Esa berdasarkan Pancasila.Pendidikan karakter berfungsi untuk:Pertama, mengembangkan potensi dasar agar berhati baik, berpikiran baik, dan berperilaku baik. Kedua, memperkuat dan membangun perilaku bangsa yang multikultur.Ketiga, meningkatkan peradaban bangsa yang kompetitif dalam pergaulan dunia.Keempat, pendidikan karakter dilakukan melalui berbagai media yang mencakup keluarga, satuan pendidikan, masyarakat sipil, masyarakat politik, pemerintah, dunia usaha, dan media massa.

Satuan pendidikan sebenarnya selama ini sudah mengembangkan dan melaksanakan nilai-nilai pembentuk karakter melalui program operasional satuan pendidikan masing-masing.Hal ini merupakan prakondisi pendidikan karakter pada satuan pendidikan yang untuk selanjutnya pada saat ini diperkuat dengan 18 nilai hasil kajian empirik Pusat Kurikulum. Nilai prakondisi (the existing values) yang dimaksud antara lain takwa, bersih, rapih, nyaman, dan santun.Dalam rangka lebih memperkuat pelaksanaan pendidikan karakter telah teridentifikasi 18 nilai yang bersumber dari agama, Pancasila, budaya, dan tujuan pendidikan nasional, yaitu: jujur, toleransi, disiplin, kerja keras, kreatif, mandiri, demokratis, rasa ingin tahu, semangat kebangsaan, cinta tanah air,menghargai prestasi,bersahabat/komunikatif, cinta damai, gemar membaca,peduli lingkungan,peduli sosial,tanggung jawab dan religius(Puskur. Pengembangan dan Pendidikan Budaya \& Karakter Bangsa: Pedoman Sekolah. 2009:9-10).

Meskipun telah terdapat 18 nilai pembentuk karakter bangsa, namun satuan pendidikan dapat menentukan prioritas pengembangannya dengan cara melanjutkan nilai prakondisi yang diperkuat dengan beberapa nilai 
yang diprioritaskan dari 18 nilai di atas. Dalam implementasinya jumlah dan jenis karakter yang dipilih tentu akan dapat berbeda antara satu daerah atau sekolah yang satu dengan yang lain. Hal itu tergantung pada kepentingan dan kondisi satuan pendidikan masing-masing. Di antara berbagai nilai yang dikembangkan, dalam pelaksanaannya dapat dimulai dari nilai yang esensial, sederhana, dan mudah dilaksanakan sesuai dengan kondisi masing-masing sekolah/wilayah, yakni bersih, rapih, nyaman, disiplin, sopan dan santun.

\section{Pentingnya Pendidikan Karakter}

Pendidikan yang diterapkan di sekolah-sekolah juga menuntut untuk memaksimalkan kecakapan dan kemampuan kognitif. Dengan pemahaman seperti itu, sebenarnya ada hal lain dari anak yang tak kalah penting yang tanpa kita sadari telah terabaikan, yaitumemberikanpendidikan karakter pada anak didik. Pendidikan karakter penting artinya sebagai penyeimbang kecakapan kognitif.Beberapa kenyataan yang sering kita jumpai bersama, seorang pengusaha kaya raya justru tidak dermawan, seorang politikus malah tidak peduli pada tetangganya yang kelaparan, atau seorang guru justrutidak prihatin melihat anak-anak jalanan yang tidak mendapatkan kesempatan belajar di sekolah.Itu adalah bukti tidak adanya keseimbangan antara pendidikan kognitif dan pendidikan karakter.Ada sebuah kata bijak mengatakan "ilmu tanpa agama buta, dan agama tanpa ilmu adalah lumpuh". Sama juga artinya bahwa pendidikan kognitif tanpa pendidikan karakter adalah buta.Hasilnya, karena buta tidak bisa berjalan, berjalan pun dengan asal nabrak. Kalaupun berjalan dengan menggunakan tongkat tetap akan berjalan dengan lambat. Sebaliknya, pengetahuan karakter tanpa pengetahuan kognitif, maka akan lumpuh sehingga mudah disetir, dimanfaatkan dan dikendalikan orang lain. Untuk itu, penting artinya untuk tidak mengabaikan pendidikan karakter anak didik.

Pendidikan karakter adalah pendidikan yang menekankan pada pembentukan nilai-nilai karakterpada anak didik.Penulis mengutip empat ciri dasar pendidikan karakter yang dirumuskan oleh seorang pencetus pendidikan karakter dari Jerman yang bernama FW Foerster:

1. Pendidikan karakter menekankan setiap tindakan berpedoman terhadap nilai normatif. Anak didik menghormati norma-norma yang ada dan berpedoman pada norma tersebut.

2. Adanya koherensi atau membangun rasa percaya diri dan keberanian, dengan begitu anak didik akan menjadi pribadi yang teguh pendirian dan tidak mudah terombang-ambing dan tidak takut resiko setiap kali menghadapi situasi baru.

3. Adanya otonomi, yaitu anak didik menghayati dan mengamalkan aturan dari luar sampai menjadi nilai-nilai bagi pribadinya. Dengan begitu, anak didik mampu mengambil keputusan mandiri tanpa dipengaruhi oleh desakan dari pihak luar.

4. Keteguhan dan kesetiaan. Keteguhan adalah daya tahan anak didik dalam mewujudkan apa yang dipandang baik. Dan kesetiaan merupakan dasar penghormatan atas komitmen yang dipilih.

Pendidikan karakter penting bagi pendidikan di Indonesia. Pendidikan karakter akan menjadi basis atau dasar dalam pembentukan karakter berkualitas bangsa, yang tidak mengabaikan nilai-nilai sosial seperti toleransi, kebersamaan, kegotongroyongan, saling membantu dan mengormati dan sebagainya.Pendidikan karakter akan melahirkan pribadi unggul yang tidak hanya memiliki kemampuan kognitif saja namun memiliki karakter yang mampu mewujudkan kesuksesan. Berdasarkan penelitian di Harvard University Amerika Serikat, ternyata kesuksesan seseorang tidak semata-mata ditentukan oleh pengetahuan dan kemampuan teknis dan kognisinyan (hard skill) saja, tetapi lebih oleh kemampuan mengelola diri dan orang lain (soft skill).

Penelitian ini mengungkapkan, kesuksesan hanya ditentukan sekitar 20 persen hard skill dan sisanya 80 persen oleh soft skill.Dan, kecakapan soft skill ini terbentuk melalui pelaksanaan pendidikan karater pada anak didik.Berpijak pada empat ciri dasar pendidikan karakter di atas, kita bisa menerapkannya dalam 
polapendidikan yang diberikan pada anak didik. Misalanya, memberikan pemahaman sampai mendiskusikan tentang hal yang baik dan buruk, memberikan kesempatan dan peluang untuk mengembangkan dan mengeksplorasi potensi dirinya serta memberikan apresiasi atas potensi yang dimilikinya, menghormati keputusan dan mensupport anak dalam mengambil keputusan terhadap dirinya, menanamkan pada anakdidik akan arti keajekan dan bertanggungjawab dan berkomitmen atas pilihannya. Menurut Penulis, sebenarnya yang terpenting bukan pilihannnya, namun kemampuan memilih dan pertanggungjawaban kita terhadap pilihan kita tersebut, yakni dengan cara berkomitmen pada pilihan tersebut.

Pendidikan karakter hendaknya dirumuskan dalam kurikulum, diterapkan metode pendidikan, dan dipraktekkan dalam pembelajaran.Selain itu, di lingkungan keluarga dan masyarakat sekitar juga sebaiknya diterapkan pola pendidikan karakter. Dengan begitu, generasi-generasi Indonesia yang unggul akan dilahirkan dari sistem pendidikan karakter.Hal ini dimulai dari orang dewasa selaku pendidikan pertama dan utama di dalam keluarga, di lembaga pendidikan terutama sekolah - sekolah dan perguruan tinggi.Jadi bapak dan mama, para guru dan dosen harus menjadi teladan hidup bagi semua peserta didik dan mahasiswa.

\section{Proses Pembentukan Karakter Kepada Anak}

Suatu hari seorang anak laki-laki sedang memperhatikan sebuah kepompong, eh ternyata di dalamnya ada kupu-kupu yang sedang berjuang untuk melepaskan diri dari dalam kepompong. Kelihatannya begitu sulitnya, kemudian si anak laki-laki tersebut merasa kasihan pada kupu-kupu itu dan berpikir cara untuk membantu si kupu-kupu agar bisa keluar dengan mudah. Akhirnya si anak laki-laki tadi menemukan ide dan segera mengambil gunting dan membantu memotong kepompong agar kupu-kupu bisa segera keluar dr sana. Alangkah senang dan leganya si anak laki laki tersebut.Tetapi apa yang terjadi? Si kupu-kupu memang bisa keluar dari sana. Tetapi kupu-kupu tersebut tidak dapat terbang, hanya dapat merayap.Apa sebabnya?Ternyata bagi seekor kupu-kupu yang sedang berjuang dari kepompongnya tersebut, yang mana pada saat dia mengerahkan seluruh tenaganya, ada suatu cairan didalam tubuhnya yang mengalir dengan kuat ke seluruh tubuhnya yang membuat sayapnya bisa mengembang sehingga ia dapat terbang, tetapi karena tidak ada lagi perjuangan tersebut maka sayapnya tidak dapat mengembang sehingga jadilah ia seekor kupu-kupu yang hanya dapat merayap.

Itulah potret singkat tentang pembentukan karakter, akan terasa jelas dengan memahami contoh kupukupu tersebut. Seringkali orangtua dan guru, lupa akan hal ini. Bisa saja mereka tidak mau repot, atau kasihan pada anak. Kadangkala Good Intention atau niat baik kita belum tentu menghasilkan sesuatu yang baik.Sama seperti pada saatmengajar anak-anak.Kadangkala orang dewasa membantu karena kasihan atau rasa sayang, tapi sebenarnya malah membuat anak-anak tidak mandiri.Membuat potensi dalam dirinya tidak berkembang.Memandulkan kreativitasnya, karena tidak tega melihat anak-anak mengalami kesulitan atau tantangan, yang sebenarnya jika berhasil melewatinya justru menjadi kuat dan berkarakter.

Sama halnya bagi pembentukan karakter seorang anak, memang butuh waktu dan komitmen dari orangtua dan sekolah atau guru untuk mendidik anak menjadi pribadi yang berkarakter.Butuh upaya, waktu dan cinta dari lingkungan yang merupakan tempat dia bertumbuh, cinta disini jangan disalah artikan memanjakan. Jika tiap orang taat dengan proses ini maka dampaknya bukan ke anak kita, kepada kitapun berdampak positif, paling tidak karakter sabar, toleran, mampu memahami masalah dari sudut pandang yang berbeda, disiplin dan memiliki integritas terpancar dari tiap orangtua ataupun guru. Hebatnya, proses ini mengerjakan pekerjaan baik bagi orangtua, guru dan anak jika semuanyaberkomitmen pada proses pembentukan karakter. Segala sesuatu butuh proses, mau jadi jelek pun butuh proses. Anak yang nakal itu juga anak yang disiplin.Dia disiplin untuk bersikap nakal.Dia tidak mau mandi tepat waktu, bangun pagi selalu telat, selalu konsisten untuk tidak mengerjakan tugas dan wajib tidak menggunakan seragam lengkap. 
Karakter suatu bangsa merupakan aspek penting yang mempengaruhi pada perkembangan sosialekonomi. Kualitas karakter yang tinggi dari masyarakat tentunya akan menumbuhkan keinginan yang kuat untuk meningkatkan kualitas bangsa. Pengembangan karakter yang terbaik adalah jika dimulai sejak usia dini. Sebuah ungkapan yang dipercaya secara luas menyatakan “ jika kita gagal menjadi orang baik di usia dini, di usia dewasa kita akan menjadi orang yang bermasalah atau orang jahat”.Thomas Lickona mengatakan "seorang anak hanyalah wadah di mana seorang dewasa yang bertanggung jawab dapat diciptakan”. Karenanya, mempersiapkan anak adalah sebuah strategi investasi manusia yang sangat tepat. Sebuah ungkapan terkenal mengungkapkan "Anak-anak berjumlah hanya sekitar 25\% dari total populasi, tapi menentukan 100\% dari masa depan". Sudah terbukti bahwa periode yang paling efektif untuk membentuk karakter anak adalah sebelum usia 10 tahun. Diharapkan pembentukan karakter pada periode ini akan memiliki dampak yang akan bertahan lama terhadap pembentukan moral anak.

Efek berkelanjutan (multilier effect) dari pembentukan karakter positif anak akan dapat terlihat, seperti yang digambarkan oleh Jan Wallander, "Kemampuan sosial dan emosi pada masa anak-anak akan mengurangi perilaku yang beresiko, seperti konsumsi alkohol yang merupakan salah satu penyebab utama masalah kesehatan sepanjang masa; perkembangan emosi dan sosial pada anak-anak juga dapat meningkatkan kesehatan manusia selama hidupnya, misalnya reaksi terhadap tekanan yang akan berdampak langsung pada proses penyakit; kemampuan emosi dan sosial yang tinggi pada orang dewasa yang memiliki penyakit dapat membantu meningkatkan perkembangan fisiknya."

Sangatlah wajar jika banyak orang mengharapkan keluarga sebagai pelaku utama dalam mendidik dasardasar moral pada anak.Akan tetapi banyak anak, terutama anak-anak yang tinggal di daerah miskin, tidak memperoleh pendidikan moral dari orang tua mereka.Kondisi sosial-ekonomi yang rendah berkaitan dengan berbagai permasalahan, seperti kemiskinan, pengangguran, tingkat pendidikan rendah, kehidupan bersosial yang rendah, biasanya berkaitan juga dengan tingkat stres yang tinggi dan lebih jauh lagi berpengaruh terhadap pola asuhnya.Sebuah penelitian menunjukkan bahwa anak-anak yang tinggal di daerah miskin 11 kali lebih tinggi dalam menerima perilaku negatif (seperti kekerasan fisik dan mental, dan ditelantarkan) daripada anak-anak dari keluarga yang berpendapatan lebih tinggi.

Banyak hasil studi menunjukkan bahwa anak-anak yang telah mendapat pendidikan pra-sekolah mempunyai kemampuan yang lebih tinggi daripada anak-anak yang tidak masuk ke TK, terutama dalam kemampuan akademik, kreativitas, inisiatif, motivasi, dan kemampuan sosialnya. Anak-anak yang tidak mampu masuk ke TK umumnya akan mendaftar ke SD dalam usia sangat muda, yaitu 5 tahun. Hal ini akan membahayakan, karena mereka belum siap secara mental dan psikologis, sehingga dapat membuat mereka merasa tidak mampu, rendah diri, dan dapat membunuh kecintaan mereka untuk belajar. Dengan demikian sebuah program penanganan masalah ini dibutuhkan untuk mempersiapkan anak dengan berbagai pengalaman penting dalam pendidikan prasekolah.Adalah hal yang sangat penting untuk menggerakkan masyarakat di daerah miskin untuk mulai memasukkan anaknya ke prasekolah dan mengembangkan lingkungan bersahabat dengan TK lainnya untuk bersama-sama melakukan pendidikan karakter.

Dorothy Law Nolte pernah menyatakan bahwa anak belajar dari kehidupan lingkungannya. Lengkapnya adalah: "Jika anak dibesarkan dengan celaan, ia belajar memaki. Jika anak dibesarkan dengan permusuhan, ia belajar berkelahi. Jika anak dibesarkan dengan cemoohan, ia belajar rendah diri. Jika anak dibesarkan dengan penghinaan, ia belajar menyesali diri. Jika anak dibesarkan dengan toleransi, ia belajar menahan diri. Jika anak dibesarkan dengan pujian, ia belajar menghargai. Jika anak dibesarkan dengan sebaik-baik perlakuan, ia belajar keadilan. Jika anak dibesarkan dengan rasa aman, ia belajar menaruh kepercayaan. Jika anak dibesarkan dengan 
dukungan, ia belajar menyenangi diri. Jika anak dibesarkan dengan kasih sayang dan persahabatan, ia belajar menemukan cinta dalam kehidupan".

Menurut pendapat presiden Jokowi."Revolusi mental itu artinya membangun manusianya dulu, membangun jiwanya.Pendidikan mulai dari SD persentasenya 70-30 persen pembangunan karakter, sikap, perilaku dan budi pekerti.Menginjak ke tingkatan SMP, 60-40 karakter juga masih ada.SMA/SMK 80-20 persen, karakter.Tanpa pembangunan manusia yang kita dahulukan, sekaya apapun sebuah negara, provinsi, ya, percuma.Kuncinya di pembangunan manusia," tandasnya.

\section{PENUTUP}

Dalam rangka pembelajaran pendidikan budi pekerti sebagai substansi dan praksis pendidikan yang terintegrasi dalam sejumlah mata pelajaran yang relevan dan iklim sosial-budaya sekolah. Pendidikan karakter pada intinya bertujuan membentuk bangsa yang tangguh, kompetitif, berakhlak mulia, bermoral, bertoleran, bergotong royong, berjiwa patriotik, berkembang dinamis, berorientasi ilmu pengetahuan dan teknologi yang semuanya dijiwai oleh iman dan takwa kepada Tuhan yang Maha Esa berdasarkan Pancasila. Pendidikan karakter dilakukan melalui berbagai media yang mencakup keluarga, satuan pendidikan, masyarakat sipil, masyarakat politik, pemerintah, dunia usaha, dan media massa. Karena itu pendidikan karakter sebagai bagian dari revolusi mental merupakan bagian yang mengutamakan pengembangan afeksi dan perilaku, maka sistem penilainya lebih mengutamakan penggunaan alat penilaian non-tes seperti laporan pribadi, laporan teman, evaluasi diri, dan portofolio (kumpulan pengalaman yang dilakukan). Alat penilaian berupa tes yang cocok untuk digunakan adalah skala sikap. Semua ini bertujuan agar pendidikan karakter yang diharapkan dapat berjalan dengn efektif

\section{Kepustakaan}

\section{Buku}

Haryono, Daniel. Kamus Besar Bahasa Indonesia. Edisi Baru, Jakarta, 2009. hal.413.

Jihat Asep, Drs, Suyanto, Prof. Ph.D. Menjadi Guru Profesional, Strategi Meningkatkan Kualwikasi dan kualitas Guru di era Global. Penerbit Erlangga, Jakarta, 2013

Manullang Belferik, dan Prayitno,MSc.Ed. Pendidikan Karakter. Gramedia Widiasarana Indonesia, Jakarta, 2011

Martono, Lydia Harlina Harlina, Pencegahan dan Penanggungan Penyalagunaan Narkoba berbasis sekolah. PT. Balai Pustaka, Jakarta, 2006

Shapiro, Lawrence,Ph.D, Mengajarkan Emosional Intelegence Pada Anak,Gramedia, Jakarta, 2001.Hal. 57

Sulaiman T. 2005. Kejujuran Membawa Sengsara. Edisi I. Jakarta. Penerbit Erlangga.

Suparno P, dkk. 2003. Pendidikan Budi Pekerti. Yogyakarta : Penerbit Kanisius.

Winataputra Udin, dkk.2001. Pedoman Umum Pendidikan Budi pekerti. Depertemen Pendidikan Nasional. Direktorat Jendral pendidikan Dasar dan Menengah. Jakarta. 
Yusuf Qosim Nanang. 2009. The 7 Awareness 7 kesadaran Hati dan Jiwa Menuju Manusia diatas Rata-rata. Jakarta.Penerbit PT.Gramedia Pustaka Utama.

\section{Internet}

www.solomoncell.wordpress.com/2012/04/14/pentingnya-nilai-kejujuran/ diambil pada tanggal 4 Agustus 2013, pukul 22.40 wib.

www.suksesitubebas.com/2012/07/14/pengertian-kejujuran/oleh rian diambil pada tanggal 4 Agustus 2013, pukul 23.01 wib.

www.bengkulukota.go.id/v2/sermon/mengapa-sulit-berkata-jujur/ by verse diambil pada tanggal 5 Agustus 2013, pukul $20.00 \mathrm{wib}$ 